\title{
Analysis of Learning Obstacles of Junior High School Students on The Topic of Circle
}

\author{
Nadia Ulfa*, Al Jupri, Darhim, Kartika \\ Mathematics Education Department, Faculty of Mathematics and Science Education, Universitas Pendidikan Indonesia, \\ Jl. Setiabudhi No 229 Bandung 40154, Indonesia. Tel. +62-81321990304. \\ Email*: nadiaulfa@upi.edu
}

\begin{abstract}
Geometry is one of the subjects in mathematics school that is important to learn, because through geometry, almost every daily problem can be solved. However, the achievements of Indonesian students in the field of geometry are still relatively low. This study aims to identify the possibility of students' learning obstacles in one area of geometry, which is circle subject. The method used in this study was qualitative research method with survey-based research design, involved 30 eight-grade students from a junior high school in Bandung. The data were collected by triangulation method using an instrument test consisting of tests of students mathematical comprehension ability that is related to circle subject, and the non-test instruments used consist of collection of observations, guidelines for student interviews, and study documents. Results showed that there were identified any types of learning obstacle caused by epistemological obstacle among others (1) learning obstacle related to the concept of sector caused by an error in the perspective of students, (2) learning obstacle related to the form of geometrical representation from the central angle of the circle caused by the student's limited knowledge of the central angle and chord of the circle. In addition, also found types of learning obstacle caused by didactical obstacle, among others (1) learning obstacle related to communication skills in presenting the definition of sector concept caused by not creating discussion and presentation activities when learning takes place, and (2) learning obstacle related the concept of the relationship between the diameter with chord of the circle caused by the presentation of material that is less detailed either provided by the teacher or presented in the source book used.
\end{abstract}

Keywords: analysis, circle, didactical obstacle, epistemological obstacle, and learning obstacles.

\section{INTRODUCTION}

Geometry is one of the fields of study in school mathematics material that is important to study. Through geometry, some daily problems can be solved (Sudihartinih and Mulyana, 2014). The purpose of teaching geometry in schools is conveyed by Sabandar (in Mulyana, 2003) that teaching geometry in schools is expected to provide a systematic attitude and habit for students to be able to give a picture of the relationships between geometric shapes and its classifications.

But in reality, the achievements of Indonesian students in the field of geometry are still relatively low. This is based on empirical evidence in the field from several studies, namely: research conducted by Lee, Gring and Dion (2007) concerning data on mathematical ability of students in Indonesia which shows that the average geometry ability of junior high school students is the lowest when compared to the topic other mathematical topics. Other studies that are in line are research conducted by Ikhsan (2012) which says that there are still many students who experience difficulties in learning geometry. This causes the achievement of understanding is not optimal.

The circle is one of the material in the field of geometry in junior high school. The position of the circle material learned in class VIII is as students' initial knowledge to learn the next material such as the material to be learned in class IX, namely to build curved side spaces that study the surface area and volume of tubes, cones and balls. So if students cannot master the circle material in class VIII well, it will have difficulty in mastering the material at the next level.

In conducting the learning process as an effort to gain knowledge, often an individual experiences obstacles and obstacles (Muslim, Mulyani, and Prabawati, 2017). Naturally, students as learners might experience the situation. This situation is called a learning barrier. If the repetitive learning obstacle continue, it will have an adverse impact on the quality of student learning in subsequent material (Alfian, 2016).

According to Brousseau (2002) states that there are three factors causing the emergence of learning obstacle, namely ontogeny obstacle (related to mental learning readiness), didactical obstacle (related to teacher teaching) and epistemological obstacle (related to student knowledge which has a limited application context ). The problems in this research are: (1) what are the learning obstacle on the topic of circle?; (2) what factors cause learning obstacle on the topic of circle?

Based on the formulation of the problem, the purpose of this research is to identify the learning obstacle on the topic of circle and to determine the factors causing the learning obstacle. This research is very important to do, because the results of this study can be used as a reference in developing learning designs that can 
minimize the occurrence of learning obstacle again in subsequent learning.

\section{METHODS}

This study used qualitative research methods. Qualitative research methods used in this study are intended to obtain in-depth data about junior high school students' obstacle learning on circle material in natural conditions (without manipulation). The research design in qualitative research is not rigid, meaning that qualitative research compiles designs that are continuously adapted to field realities. The research design in this study used a survey research design.

The number of subjects in this study were students in one class ranging from 30 people who came from one junior high school in the city of Bandung. The selection of the subject of this research takes into account the following: Students who have heterogeneous abilities in one class, students who will get circle material and the kinship between researchers and teachers who teach in the class. Students for interview participants were chosen based on indications from learning obstacle, 12 students were selected.

In this study several data collection techniques were used including observation, interviews, tests, and study documents. The research instrument consisted of the main instruments and supporting instruments. The main instrument is the researcher himself, while the supporting instruments are divided into two namely the test instrument and the non-test instrument. The test instruments in this study were 3 essay questions and the non-test instruments in this study were observation and interview guidelines. The following are the test instruments used in this study.

1. Note the picture below, which illustrates the sector of circle?

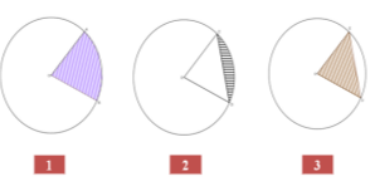

If so, what is meant by sector of circle? Give a complete and clear explanation!

2. Pay attention to the circles with center $\mathrm{O}$ below!

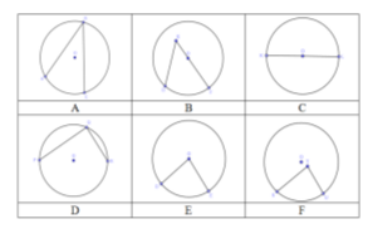

From the circle images above, which circle has

a. The center angle of the circle, explain!

b. The angle around the circle, explain!

c. Not both, explain!
3. Perhatikan gambar di samping!

Diketahui lingkaran dengan pusat $\mathrm{O}$ dan jari-jari 7 cm. Tentukan luas daerah yang diarsir!

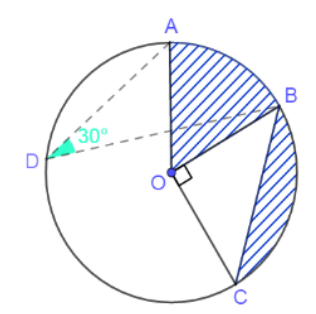

The data obtained from the data collection process is then processed and analyzed using the Miles and Huberman model (in Sahid, 2011) which is divided into 3 stages, namely (1) data reduction, in which data from observations and interviews are processed in the form of transcripts and result data The test is given a code of each student's answer, then the student's answer is chosen which represents the alleged learning barrier in solving the problem in the circle material. The reduced data then goes to step (2) of data presentation, where data from observations and interviews are presented in the form of transcript quotations while the test results are presented in the form of images and analysis results of each data are presented descriptively. The third stage is (3) drawing conclusions where the data that has been reduced and presented will be examined carefully for drawing conclusions.

\section{RESULTS AND DISCUSSION}

\section{Results (Types of Learning Obstacle)}

Based on the results of research data collection, researchers found several types of learning obstacles in the circle material as follows.

a. Learning obstacle type 1: Learning obstacle to student learning related to the concept of sector.

This type of learning obstacle was initially found from students answer when answering question no. 1, namely:

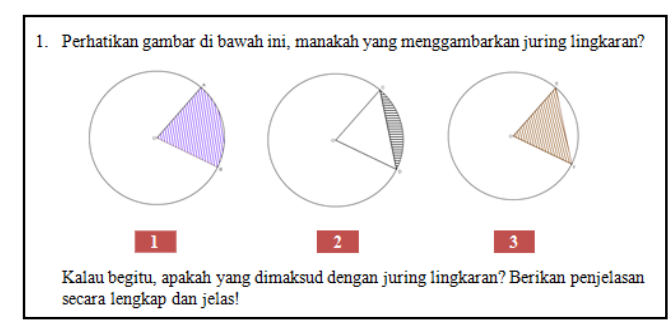

Figure 1. Problem Number 1.

Can be seen in figure 1, students are asked to first choose which circle illustrates the sector of circle, then students are asked to define the sector of circle. The following is the form of answers from student 2 (S2). 
1. gambar dibawdo yg meru pakan iuripa adalah nompr 2 juring adalah goris yg memotong linghrar

Figure 2. Answer from student 2 (S2) in problem number 1.

Can be seen in figure 2, the answer is an incorrect answer. In the interview results, it was found that there was a mistake in representing the geometrical form of the concept of sector and tembereng. S2 also repeated his mistake in answering a similar question in question no. 3.

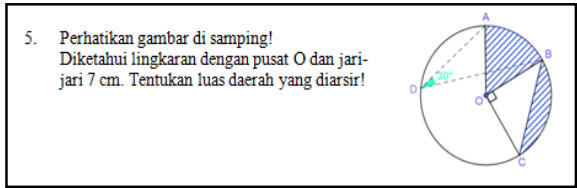

Figure 3. Problem Number 3.

Based on the results of the interview, students assumed that the shaded area that was asked about question number 3 in both the $\mathrm{AOB}$ and $\mathrm{BC}$ regions was tembereng, although in fact the AOB area was sector.

b. Learning obstacle type 2: Learning obstacle to student learning related to communication skills in presenting the definition of sector concepts.

This type of learning obstacle is also found on the student answer sheet when answering question number 1, as follows:

$$
\begin{aligned}
\text { 1. Lingkaran yang menggambarkan juring lingkaran yaitu nomer I } \\
\text { Juring ungkaran } \Rightarrow \text { daerah yang diarsir / Luas daerah } \\
\text { yang diarsir yang terletak di } \\
\text { Lingkaran. }
\end{aligned}
$$

Figure 4 Answer from student 10 (S10) in problem number 1.

Can be seen in figure 4 , the definition that S10 includes is a less specific definition. From the results of the interview process, students are actually able to distinguish which is sector and which is not sector. However, there are difficulties in communicating the formal definition of the concept of sector.

c. Learning obstacle type 3: Learning obstacle to student learning in recognizing various forms of geometrical representations from the center angle of the circle.

This type of learning obstacle is found from the student answer sheet when answering question no. 2, namely:

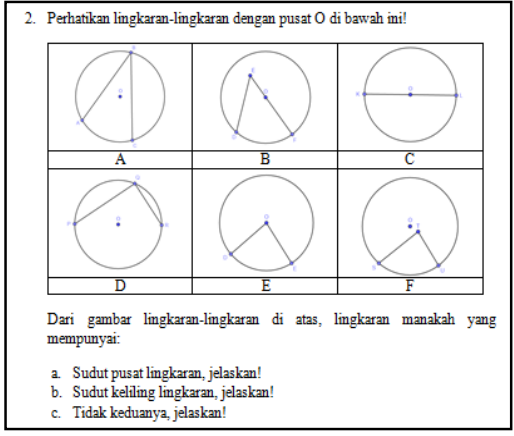

Figure 5 Problem No 2.

Can be seen in figure 5, Problem Number 2 is a problem with the concept of the central angle and the angle around the circle. To answer problem number 2, students need to understand the definitions of the two concepts and know the various geometric shapes. The following is the form of answers from students 1 (S1)

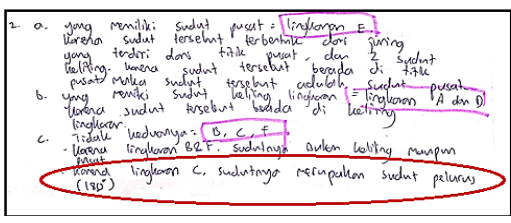

Figure 6 Answer from student 1 (S1) in problem number 2.

Can be seen in figure 6, S1 only recognizes circle $\mathrm{E}$ as a circle which represents the central angle of the circle, whereas in circle $\mathrm{C}, \mathrm{S} 1$ recognizes it as an alignment angle. This is an indication of the learning obstacle experienced by $\mathrm{S} 1$ in terms of recognizing various forms of geometrical representation from the center of the circle.

d. Learning obstacle type 4: Learning obstacle to student learning are related to the concept of the relationship between diameter and the chord.

Based on the results of interviews of several students, there was an indication of learning obstacle where students had difficulty in defining the chord and incorrectly understanding the concept of the relationship between diameter and chord. One of the students who experienced difficulties was student 6 (S6) who said that the diameter was not a chord.

\section{Discussion}

After identifying the types of learning obstacles (learning obstacle) experienced by students, the next step is to find out the factors causing these obstacles. Following is a description of the causative factors of each type of learning obstacle found. 


\section{a. Didactical Obstacle}

1) Learning that does not create discussion activities that result in learning obstacle type 2 occurs.

Based on the observations of researchers during the learning circle material, learning created by the teacher does not lead to one of the situations in didactic situation theory, namely the formulation situation, where students should unite the understanding and strategies that have been owned by interacting with other students. In this situation it is also possible for students to discuss with each other about their understanding both in pairs and in groups (Septyawan, 2018). Based on Ningrum's (2016) research, student-centered learning and group discussions and class discussions provide many opportunities for students to communicate their ideas, knowledge and thoughts.

2) There is a presentation of material that is less detailed on the concept of a chord that causes learning obstacle type 4 occurs.

Based on observations obtained that the teacher defines a chord as "a straight line cutting a circle at two points". Researchers suspect that if the definition is used in the learning of the chord concept material in class, it will potentially lead to learning obstacles experienced by students, because these concepts can produce erroneous understanding. Just as there are some students who think that the diameter is not a chord on the grounds that the diameter does not intersect the circle at two points but at three points.

Based on the results of a study of documents conducted by researchers in the source book used, found indications of didactic obstacles. The following is a picture of a fragment of the source book about the concept of a chord.

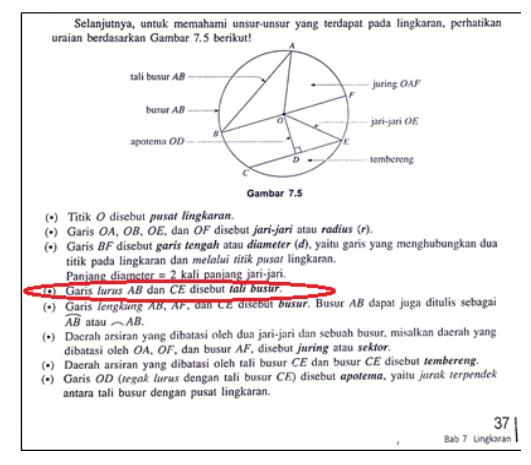

Figure 7 The fragment of the source book

Can be seen in figure 7, it appears that the concept of the chord given in the source book is incomplete. The source book only presents an illustration of an image that is an example of a chord, while the formal definition of the chord is not included. This further reinforces that learning obstacle type 4 related to the concept of the relationship between diameter and chord, due to the didactical obstacle in the presentation of less detailed material either provided by the teacher or presented in the source book.

\section{b. Epistemological Obstacle}

1) There is a incorrect perspective at students on the concept of sector, which results in learning obstacle type 1 occurrs.

The incorrect perspective of S2 is one indication that S2 experienced an epistemological obstacle in the concept of sector. The existence of epistemological obstacle experienced by S2 is further strengthened by how S2 repeats wrong answers to the same problem. Based on what has been described previously, where $\mathrm{S} 2$ repeats mistakes regarding the same problem related to the concept of sector. According to the researchers' suspicion, the factor that caused this to happen was the perspective of S2 which was wrong on the concept of sector, this meant that S2 experienced difficulties with an epistemological obstacle.

2) The students' knowledge is limited to the concept of the central angle and the chord, where students assume that "the central angle must be formed from sector" and "the chord must be in the sector area". This has resulted in learning obstacle type 3 occurs.

\section{CONCLUSION}

Based on the results of the interviews, obtained the S1 thought process, starting from students having an understanding that "the central angle was formed from sector" this resulted in students answering that picture no $2 \mathrm{c}$ does not illustrate the concept of central angle. Furthermore, the researcher also found other indications where S1 has a limited context in its understanding of the concept of the chord which he considers that "the chord does not cross the center". Another understanding that makes S1 also experiencing difficulties is about its understanding that "the chord must be in the sector area". In this problem S1 has difficulty finding sector if the diameter is a chord. This results in students concluding that the circle in section $2 \mathrm{c}$ is not a central angle because students do not find the sector. Incorrect understanding is the cause of student errors. Researchers suspect that it is included in the type of learning obstacle that is epistemological obstacle because the S1 knowledge has a limited context at the central angle and chord.

\section{ACKNOWLEDGEMENTS}

I thank the teacher and students who have been involved in this research process. 


\section{REFERENCES}

Amir, M.F. (2015). Analisis Kesalahan Mahasiswa PGSD Universitas Muhammadiyah Sidoarjo dalam Menyelesaikan Soal Pertidaksamaan Linier. Jurnal Edukasi, 1(2). Sidoarjo: Universitas Muhammadiyah Sidoarjo. Diakses dari https://scholar.google.co.id/citations?user=owOgu_gAAAAJ \&hl=en\#d=gs_md_cita-

$\mathrm{d} \& \mathrm{u}=\% 2 \mathrm{Fcitations} \% 3 \mathrm{Fview} \_$op\%3Dview_citation\%26hl\%3D en\%26user\%3DowOgu_gAAAAJ\%26citation_for_view\%3D owOgu_gAAAAJ\%3AzYLM7Y9cAGgC\%26tzom\%3D-420. Pada tanggal 13 Januari 2019.

Brousseau, G. (2002). Theory of didactical situation in mathematics (Vol.19). New York: Kluwer Academic Publishers

Ikhsan, M. (2012). Pengembangan Model Pembelajaran Berbasis Teori Ban Hiele untuk Meningkatkan Kemampuan Geometri Siswa SMP di Kota Banda Aceh. Jurnal Pengajaran MIPA, 17(2). Banda Aceh: Universitas Syiahkuala. [Online]. Diakses dari

http://journal.fpmipa.upi.edu/index.php/jpmipa/article/view/22 9/144. Pada tanggal 12 Januari 2019.

Lee, J., Grigg, W \& Dion, G. (2007). The Nation's Report Card: Mathematic 2007 (NCES 2007-494). National Center for Education Statistics, Institute of Education Sciences. U.S. Department of Education, Washington, D.C.

Mulyana, E. (2003). Masalah Ketidaktepatan Istilah dan Simbul dalam Geometri SLTP Kelas 1. Bandung. Univeristas Pendidikan Indonesia. Diakses dari http://file.upi.edu/Direktori/FPMIPA/JUR._PEND._MATEM
ATIKA/195401211979031-

ENDANG_MULYANA/MAKALAH/Psikologi_geometri.pdf. Pada tanggal 13 Januari 2019.

Muslim, S.R, Mulyani, E, Prabawati, M.N. (2017). Kajian Learning Obstacle Mahasiswa Pendidikan Matematika pada Materi Trigonometri dalam Perkuliahan Kapita Selekta Sekolah Menengah. Jurnal Siliwangi, 3(2). Universitas Siliwangi.

Sahriah, S, Muksar, M, Lestari, T.E. (2012). Analisis Kesalahan Siswa dalam Menyelesaikan Soal Matematika Materi Operasi Pecahan Bentuk Aljabar Kelas VIII SMP Negeri 2 Malang. Malang: Universitas Negeri Malang.

Sahid, R. (2011). Analisis Data Penelitian Kualitatif Model Miles dan Huberman. Semarang.

Sofyana, A.U, Budiarto, M.T. (2013). Profil Keterampilan Geometri Siswa SMP dalam Memecahkan Masalah Geometri Berdasarkan Level Perkembangan Berpikir Van Hiele.Surabaya: Universitas Negeri Surabaya. Diakses dari http://jurnalmahasiswa.unesa.ac.id/index.php/mathedunesa/arti cle/view/1220. Pada tanggal 13 Januari 2019.

Sudihartinih, E, Mulyana, E. (2014). Perkuliahan Geometri Transformasi dengan Pendekatan Kontruktivisme untuk Meningkatkan Level Berpikir Geometri Van Hiele. Jurnal Pendidikan Matematika Sigma Didaktika 3(1). [Online]. Diakses dari http://repository.upi.edu/29945/1/AR_2014_EyusSudihartinih _Sigma\%20Didaktika.pdf. Pada tanggal 12 Januari 2019 
THIS PAGE INTENTIONALLY LEFT BLANK 